\title{
A review of forest and tree plantation biomass equations in Indonesia
}

\author{
Kamalakumari Anitha ${ }^{1} \cdot$ Louis V. Verchot ${ }^{1} \cdot$ Shijo Joseph $^{1} \cdot$ Martin Herold $^{2}$. \\ Solichin Manuri $^{3} \cdot$ Valerio Avitabile ${ }^{2}$
}

Received: 15 March 2014 / Accepted: 7 August 2015 /Published online: 12 October 2015

(C) The Author(s) 2015. This article is published with open access at Springerlink.com

\begin{abstract}
- Key message We compiled 2,458 biomass equations from 168 destructive sampling studies in Indonesia. Unpublished academic theses contributed the largest share of the biomass equations. The availability of the biomass equations was skewed to certain regions, forest types, and species. Further research is necessary to fill the data gaps in emission factors and to enhance the implementation of climate change mitigation projects and programs.

- Context Locally derived allometric equations contribute to reducing the uncertainty in the estimation of biomass, which may be useful in the implementation of climate change mitigation projects and programs in the forestry sector. Many regional and global efforts are underway to compile allometric equations.
\end{abstract}

Handling Editor: Erwin Dreyer

Contribution of the co-authors KA and LV conceived the idea, KA, $\mathrm{LV}, \mathrm{SJ}$, and MH designed the study, KA compiled the data, KA and SJ analyzed the data and wrote the paper, and LV, MH, SM, and VA revised the paper.

Electronic supplementary material The online version of this article (doi:10.1007/s13595-015-0507-4) contains supplementary material, which is available to authorized users.

Kamalakumari Anitha

a.kamalakumari@cgiar.org; anithasacon@gmail.com

1 Center for International Forestry Research, Jl. CIFOR, Situ Gede, Bogor 16115, Indonesia

2 Laboratory of Geo-Information Science and Remote Sensing, Wageningen University, PO Box 47, 6700

AA Wageningen, The Netherlands

3 Fenner School of Environment and Society, Australian National University, Canberra, Australia
- Aims The present study compiles the available allometric equations in Indonesia and evaluates their adequacy in estimating biomass in the different types of forest across the archipelago.

- Methods A systematic survey of the scientific literature was conducted to compile the biomass equations, including ISI publications, national journals, conference proceedings, scientific reports, and academic theses. The data collected were overlaid on a land use/land cover map to assess the spatial distribution with respect to different regions and land cover types. The validation of the equations for selected forest types was carried out using independent destructive sampling data.

- Results A total of 2,458 biomass equations from 168 destructive sampling studies were compiled. Unpublished academic theses contributed the majority of the biomass equations. Twenty-one habitat types and 65 species were studied in detail. Diameter was the most widely used single predictor in all allometric equations. The cumulative number of individual trees cut was 5,207. The islands of Java, Kalimantan, and Sumatra were the most studied, while other regions were underexplored or unexplored. More than half of the biomass equations were for just seven species. The majority of the studies were carried out in plantation forests and secondary forests, while primary forests remain largely understudied. Validation using independent data showed that the allometric models for peat swamp forest had lower error departure, while the models for lowland dipterocarp forest had higher error departure.

- Conclusion Although biomass studies are a major research activity in Indonesia due to its high forest cover, the majority of such activities are limited to certain regions, forest types, and species. More research is required to cover underrepresented regions, forest types, particular growth forms, and very large tree diameter classes. 
Keywords Allometric equations - Aboveground biomass . Forest inventory $\cdot$ REDD $+\cdot$ Indonesia

\section{Introduction}

Tropical forests store more than $25 \%$ of carbon in the terrestrial biosphere (Bonan 2008). However, the forests in the tropics are being lost at the rate of 2,100 $\mathrm{km}^{2}$ year ${ }^{-1}$ (Hansen et al. 2013), adding significantly to global net greenhouse gas (GHG) emissions (Intergovernmental Panel on Climate Change (IPCC) 2013). Emission reduction strategies such as the REDD+ mechanism under the auspices of the United Nations Framework Convention on Climate Change (UNFCCC) depend on countries being able to produce accurate and precise estimates of standing biomass stocks and changes in these stocks. The FAO FRA (2010) showed that most countries use global IPCC default values for estimating the biomass and carbon stocks in their forests, and they do not have estimates based on locally appropriate data.

The IPCC Guidelines for National Greenhouse Gas Inventories (IPCC 2006) use a tiered approach for emission inventories: tier 1, the simplest to use, is based on global default emission/removal factors, tier 2 is based on country- or region-specific data, and tier 3 uses higher order, spatially explicit data, and modelling to obtain greater certainty of estimates (IPCC 2006). The IPCC also proposes two methods, the gain-loss method and the stock-difference method, to measure the stock changes in any carbon pool and generate emission factors. The gain-loss method is a mass balance model where the net change in a given pool is the difference between additions and removals from the same pool, while the stock-difference method is based on the inventorying of stock at two time points. To implement the gain-loss or stock-difference methods across landscapes, inventory compilers need data on forest and non-forest ecosystems in order to produce emissions factors for net changes associated with land use or land use change. One of the main limitations to improving emissions factors is the lack of appropriate biomass equations for converting plot scale measurements collected in a traditional forest inventory into biomass estimates and subsequently into carbon numbers (IPCC 2006; Verchot et al. 2012; Joseph et al. 2013).

The development of allometric equations requires harvesting and weighing of trees and linking of tree structure variables such as diameter, height, and/or other dendrometric variables to the total biomass using mathematical functions. Metabolic ecological theory establishes a universal power law relationship between tree biomass and tree diameter with a fixed scaling exponent close to $8 / 3$ (West et al. 1997, 1999). However, empirical studies show that the fixing of the power relationship without considering the tree's intrinsic and extrinsic variables generates systematic overestimation of biomass
(Chave et al. 2005). The height (Feldpausch et al. 2012), wood density (Enquist et al. 1999), crown size (Goodman et al. 2014), life history strategies (Henry et al. 2010), climatic zones (Brown et al. 1989), forest type (Rutishauser et al. 2013), and site characteristics (Alvarez et al. 2012) contribute significantly to variation in the aboveground biomass. Chave et al. (2005) developed benchmark models for the tropics involving diameter, wood density, and height according to forest types. Although Chave's models perform reasonably well in certain sites in Southeast Asia (Rutishauser et al. 2013) and Africa (Vieilledent et al. 2012; Fayolle et al. 2013), most of the other studies show higher uncertainty in biomass estimates compared to those developed locally (Basuki et al. 2009; Kenzo et al. 2009a; van Breugel et al. 2011; Alvarez et al. 2012; Goodman et al. 2014). In another recent benchmark pantropical study, Feldpausch et al. (2012) showed substantial variation in biomass distribution and forest structure among regions and continents and concluded that future biomass models based on continents and regions may prove more robust than pantropical models.

Many regional and global efforts are underway to compile allometric equations to enhance biomass estimates and carbon reporting. Among the global initiatives, the recent GlobAllomeTree program (www.globallometree.org; Henry et al. 2013) has compiled 706 equations for Europe, 2,843 for North America, and 1,058 for Africa. They also reported 1,172 equations for Asia, which consisted of 1,102 from Cambodia and 70 from Indonesia. Other notable compilations include those of Queensland (Eamus et al. 2000), North America (Jenkins et al. 2003), Europe (Zianis et al. 2005), and sub-Saharan Africa (Henry et al. 2011). In Indonesia, a significant step was made by Krisnawati et al. (2012) who compiled 807 equations (437 biomass and 370 volume equations).

Indonesia is the second largest emitter of GHGs in the land use sector, accounting annually about $105 \mathrm{Tg} \mathrm{C}$ from a deforested area of 701,000 ha, between 2000 and 2005 (Harris et al. 2012). The estimation of carbon stock and stock changes has become a common subject of research in Indonesia and is driven by Indonesia's participation in the global REDD+ initiative. Very high carbon emissions during the intense fires in 1997 (Levine 1999; Page et al. 2002) raised international awareness of the importance of forest-related emissions in Indonesia (Achard et al. 2002; Houghton 2003; Miettinen et al. 2011). Saatchi et al. (2011) estimated an average carbon stock of $155 \mathrm{t} \mathrm{ha}^{-1}$ (at a threshold of $25 \%$ canopy cover) using a combined approach involving satellite data, LiDAR measurements, and field data at a spatial resolution of $1 \mathrm{~km}$. Ground level efforts were also taken up at the national level by implementing a national forestry inventory (NFI) program. There are currently 2,205 NFI plots, with a planned monitoring interval of 5 years. Although stand density and other ancillary information are available, we need to learn how to 
convert plant parameters such as diameter and height to biomass and carbon stock values.

The present study was thus designed with the aim of compiling the available biomass equations in Indonesia to support national level climate change mitigation programs and projects including REDD+ readiness activities.

\section{Materials and methods}

A systematic survey of the scientific literature was conducted to compile the biomass equations for Indonesia. The first step was to contact the leading experts working on forest biomass across the country under the assumption that the subject experts were able to provide first hand, up-to-date, and time-efficient assessments. A standard questionnaire form, asking for the status of biomass research at their region, contact information of the main research groups working in their regions, and supplementary evidence, if any, was prepared. A total of 54 experts were surveyed from a wide range of institutions including government, universities, NGOs, international, private, and other research groups focusing on Indonesia.

The sources of published literature were varied: from ISI publications, national journals, conference proceedings, scientific reports, and theses. The primary language of writing in many of the above sources was not English, except for ISI publications. Therefore, we recruited researchers fluent in both English and Indonesian (Bahasa Indonesia) languages and trained them to perform literature searches on biomass estimation. We carefully designed a matrix after reviewing key guidelines, manuals, and other international literature (Brown 1997; Jenkins et al. 2003; Zianis et al. 2005; Henry et al. 2011; Walker et al. 2011). Researchers were asked to fill out the matrix after thoroughly checking the data sources during the institutional visits. We also asked for a copy of any published materials for further checking and verification. Information on the geographical location, land use category, vegetation type, and species studied were noted for each study. The major parameters such as sample size $(n)$, diameter, and height range of the measured trees along with statistical parameters such as coefficient of determination $\left(R^{2}\right)$, standard errors, and correction factor were also noted. Additional information such as values for wood density, biomass expansion factor, and root/shoot ratio was also collected, if available.

The data were overlaid on a land use/land cover map to assess their spatial distribution and identify areas and vegetation types with no measurements. The base land use/land cover map for this assessment was obtained from the Ministry of Forestry, Government of Indonesia. This map was prepared from Landsat images with a spatial resolution of $30 \mathrm{~m}$ taken between 2009 and 2010. The original data was classified into 22 classes (Romijn et al. 2013). We reclassified them into six classes: forest land, cropland, grassland, wetland, settlements, and other land, as per the IPCC guidelines (2006). The forest land consisted of three forest types (i.e., upland, peat swamp, and mangrove) and was subdivided into intact and degraded categories. Since forests are the largest carbon pool and most affected by human activities, we retained all the six forest subclasses. Thus in total, 11 classes remained which include six forest and five non-forest classes. Allometric equations with spatial information were overlaid on the land cover map to assess the spatial distribution with respect to different regions and land cover types.

We conducted a validation exercise for some of the equations for peat swamp forest and dipterocarp forests. The data sets used for the validation are explained in Table 1 . We limit our validation efforts to the above vegetation types due to our restricted access to the destructive sample data. We excluded equations that had $R^{2}$ value less than 0.8 . In addition, we did not consider those equations that were developed from studies where the sample size was less than 15 trees, and the highest diameter was less than $20 \mathrm{~cm}$. In total, 19 equations were validated, which included 12 equations from dipterocarp forest and 7 equations from peat swamp forest (Table 2). The mean percentage error (MPE) and mean absolute percentage error (MAPE) were calculated for each equation as follows. Equations with low MAPE proved to be a good estimator, while MPE provided evidence about whether the equations were under- or overestimated.

$$
\begin{aligned}
& \mathrm{MPE}=\frac{100}{n} \sum \frac{x_{\mathrm{p}}-x_{\mathrm{m}}}{x_{\mathrm{m}}} \\
& \mathrm{MAPE}=\frac{100}{n} \sum \frac{\left|x_{\mathrm{p}}-x_{\mathrm{m}}\right|}{x_{\mathrm{m}}}
\end{aligned}
$$

where $x_{\mathrm{p}}$ and $x_{\mathrm{m}}$ are the predicted and measured biomass values, respectively.

\section{Results}

\subsection{Data sources}

The literature survey and correspondence with experts resulted in the identification of 2,458 biomass equations (ESM 1) from 168 studies (ESM 2). Publications included 15 ISI journal articles, 27 national journal articles, 16 conference proceedings, 93 theses, and 17 technical /project reports. The maximum number of allometric equations was obtained from theses (1,910 equations) followed by national and ISI journals (281 and 119 equations, respectively). Theses made up $55 \%$ of the total publications, and these publications collectively provided $78 \%$ of the equations. Similarly, ISI indexed journals contributed $5 \%$ of the total publications, which supplied $9 \%$ of the equations. National journals contributed $11 \%$ of the publications and contributed $16 \%$ of the equations (Fig. 1). 
Table 1 The destructive sampling datasets used for validating selected allometric equations in peat swamp forests (PSF) and lowland dipterocarp forest (LDF)

\begin{tabular}{llllllllll}
\hline $\begin{array}{l}\text { Forest } \\
\text { type }\end{array}$ & $N$ & $\begin{array}{l}\text { Min DBH } \\
(\mathrm{cm})\end{array}$ & $\begin{array}{l}\text { Max DBH } \\
(\mathrm{cm})\end{array}$ & $\begin{array}{l}\text { Min height } \\
(\mathrm{m})\end{array}$ & $\begin{array}{l}\text { Max height } \\
(\mathrm{m})\end{array}$ & $\begin{array}{l}\text { Min WD } \\
\left(\mathrm{g} \mathrm{cm}^{-3}\right)\end{array}$ & $\begin{array}{l}\text { Max WD } \\
\left(\mathrm{g} \mathrm{cm}^{-3}\right)\end{array}$ & Site & Source \\
\hline PSF & 66 & 5.2 & 167 & 6.4 & 49.5 & 0.36 & 0.76 & South Sumatra & Manuri et al. (2014) \\
LDF & 41 & 1 & 123.8 & 1.5 & 62.5 & 0.21 & 1.015 & $\begin{array}{c}\text { East Kalimantan Manuri et al. (2012), } \\
\text { and Sarawak Kenzo et al. (2009b) }\end{array}$ \\
\hline
\end{tabular}

\subsection{Biomass components}

A total of 87 terms were used to represent different biomass components of trees. We have segregated these terms into seven meaningful classes to match the international literature on biomass: aboveground biomass (AGB), belowground biomass (BGB), branch biomass (BrB), leaf biomass (LeB), stem biomass (SteB), total biomass (TB), and twig biomass (TwB) (Table 3). These classes include 1,408 equations contributing $57 \%$ of the equations. The most frequently studied biomass components include stem biomass (254 equations), total biomass (244 equations), leaf biomass (236 equations), and branch biomass (217 equations). The equations for total aboveground biomass and belowground biomass were 186 and 150 , respectively, which together contributed only $14 \%$ of the equations.

The equations which were not included in the above seven classes were categorized as "others." These consisted of 1,050 equations from 80 different terms of biomass components (ESM 3). The major categories in this class included leaf carbon mass (126 equations), stem carbon mass (117 equations), branch carbon mass (111 equations), and total carbon mass (94 equations). Some of the terminologies in the "other" class were confusing as there were no explicit definitions given in the publications, for example, old trunk biomass, small root biomass, big root biomass, and so on. Specialized allometric equations also noted in this study (such as aerial root biomass, flower biomass, fruit biomass) were also grouped into the

Table 2 The allometric equations selected for the validation in the present study

\begin{tabular}{|c|c|c|c|c|c|c|}
\hline $\begin{array}{l}\text { Equation } \\
\text { name }\end{array}$ & $\begin{array}{l}\text { Carbon } \\
\text { compartment } \\
\text { studied }\end{array}$ & AGB equations & $\begin{array}{l}\mathrm{r} 2 / \mathrm{r} 2 \\
\text { adjust }\end{array}$ & $\begin{array}{l}\text { No. of } \\
\text { samples }(n)\end{array}$ & $\begin{array}{l}\text { Diameter } \\
\text { range }(\mathrm{cm})\end{array}$ & Reference \\
\hline LDF1 & AGB & $\mathrm{AGB}=0.0112(\mathrm{D})^{\wedge} 2.6878$ & 0.91 & 45 & $7.0-70.0$ & Siregar and Dharmawan (2011) \\
\hline LDF2 & AGB & $\mathrm{AGB}=0.2137 \times \mathrm{D}^{\wedge} 2.445 \times \mathrm{WD}^{\wedge} 0.763$ & 0.997 & 40 & $1.1-115$ & Anggraeni (2011) \\
\hline LDF3 & AGB & $\mathrm{AGB}=0.139 \mathrm{D}^{\wedge} 2.459$ & 0.992 & 17 & $1.04-115$ & Niapele (2011) \\
\hline LDF4 & AGB & $\mathrm{AGB}=0.1 \mathrm{D}^{\wedge} 2.513$ & 0.994 & 17 & $1.1-115$ & Yunianto (2012) \\
\hline LDF5 & AGB & $\mathrm{AGB}=0.096 \mathrm{D}^{\wedge} 2.406$ & 0.976 & 23 & $6.23-31.10$ & Niapele (2011) \\
\hline LDF6 & AGB & $\mathrm{AGB}=0.111 \mathrm{D}^{\wedge} 2.532$ & 0.973 & 35 & $5.1-37.8$ & Massiri (2010) \\
\hline LDF7 & AGB & $\mathrm{AGB}=0.3517 \times \mathrm{D}^{\wedge} 2.203 \times \mathrm{WD}^{\wedge} 0.639$ & 0.985 & 83 & $5.0-70.0$ & Basuki et al. (2009) \\
\hline LDF8 & AGB & $\mathrm{AGB}=0.475 \times \mathrm{D}^{\wedge} 2.188 \times \mathrm{WD}^{\wedge} 0.832$ & 0.97 & 122 & $5.0-70.0$ & Basuki et al. (2009) \\
\hline LDF9 & AGB & $\mathrm{AGB}=0.2898 \mathrm{D}^{\wedge} 2.311$ & Not available & 39 & $5.0-70.0$ & Samalca (2007) \\
\hline LDF10 & AGB & $\mathrm{AGB}=0.08127 \times \mathrm{D}^{\wedge} 2.44$ & 0.81 & 108 & $3.2-20.3$ & Hashimoto et al. (2004) \\
\hline LDF11 & AGB & $\mathrm{AGB}=0.11 \mathrm{WD} \mathrm{D}^{\wedge} 2.62$ & Not available & 29 & $8.0-48.0$ & Ketterings et al. (2001) \\
\hline LDF12 & AGB & $\begin{array}{l}\mathrm{AGB}=0.2395 \times \mathrm{D}^{\wedge} 2.0979 \times \mathrm{H}^{\wedge} 0.4064 \times \\
\quad \mathrm{WD}^{\wedge} 1.0182\end{array}$ & 0.987 & 30 & $14-172$ & Manuri et al. (2013) \\
\hline PSF1 & AGB & $\mathrm{AGB}=0.1886 \mathrm{D}^{\wedge} 2.3702$ & 0.95 & $20 \mathrm{~m} \times 20 \mathrm{~m}$ & $>10.0$ & Istomo (2002) \\
\hline PSF2 & AGB & $\mathrm{AGB}=0.1592 \mathrm{D}^{\wedge} 2.39$ & 0.976 & 30 & $5.0-70.0$ & Febrina (2012) \\
\hline PSF3 & AGB & $\mathrm{AGB}=0.204 \mathrm{D}^{\wedge} 2.393$ & 0.97 & 52 & $5.0-63.0$ & Suwarna et al. (2012) \\
\hline PSF4 & AGB & $\mathrm{AGB}=0.153108 \mathrm{D}^{\wedge} 2.40$ & 0.978 & 20 & $2.0-30.02$ & Widyasari (2010) \\
\hline PSF5 & AGB & $\mathrm{AGB}=0.206284 \mathrm{D}^{\wedge} 2.4511$ & 0.961 & 30 & $5.0-70.0$ & Novita (2010) \\
\hline PSF6 & AGB & $\begin{array}{l}\mathrm{AGB}=0.0494 \times \mathrm{D}^{\wedge} 1.7961 \times \mathrm{H}^{\wedge} 1.2292 \times \\
\quad \mathrm{WD}^{\wedge} 0.9170\end{array}$ & 0.991 & 20 & $6.5-117$ & Manuri et al. (2013) \\
\hline PSF7 & AGB & $\mathrm{AGB}=0.1066 \times \mathrm{D}^{\wedge} 2^{\wedge} 1.243$ & 0.9 & Not available & $2.0-35.0$ & Jaya et al. (2007) \\
\hline
\end{tabular}

LDF1-12 denotes the equations from lowland dipterocarp forest and PSF1-7 is for peat swamp forests 


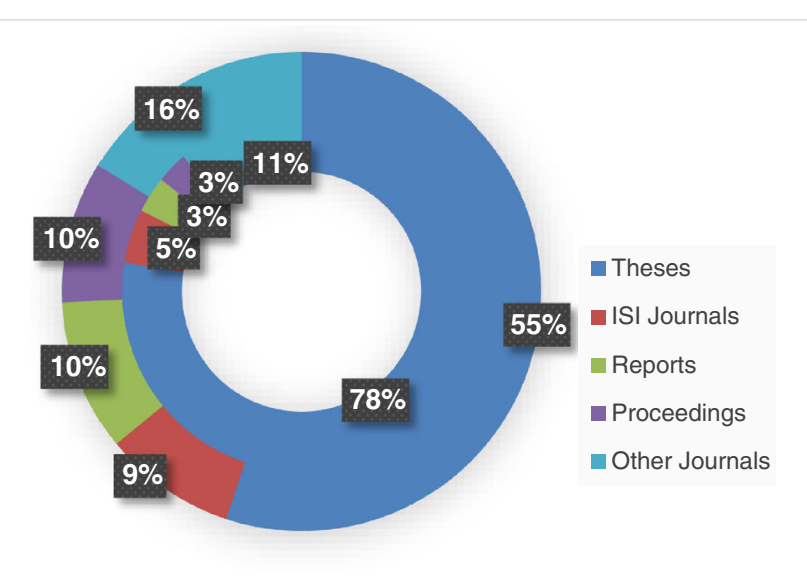

Fig. 1 The data sources for biomass studies and allometric equations in Indonesia. The outer circle represents number of studies, and the inner circle represents number of equations

"other" category as they contributed an insignificant fraction $(2 \%)$ of the biomass equations.

\subsection{Sample size and methods}

The majority of the equations $(2,339$ out of 2,458$)$ specified sample size in terms of the number of trees cut. The sample size $(n)$ ranged from 4 to 226 trees. Among the compiled studies, $41 \%$ had a sample size of less than 15 trees, $48 \%$ were based on sample sizes between 16 and 40 trees, $9 \%$ were based on sample sizes between 41 and 90 trees, and the rest ( $2 \%)$ sampled between 91 and 226 trees. The largest sample sizes were reported by Hendri et al. (2012) (226 trees), Hashimoto et al. (2004), Yamakura et al. (1986a, b) (191 trees), Miyamoto et al. (2007) (184 trees), Basuki et al. (2009) (122 trees), and Heriansyah et al. (2007) (115 trees). Six studies (30 equations) reported the number of trees cut based on plot size or as a percentage of stand population, whereas 24 studies $(89$ equations) lacked the clarity of a sampling size and method.

Table 3 The distribution of allometric equations with respect to major biomass compartments in Indonesia (for major classes in the other category, refer to ESM 3)

\begin{tabular}{lll}
\hline Biomass compartments & No. of allometric equations & Percentage \\
\hline Aboveground biomass (AGB) & 186 & 7.57 \\
Belowground biomass (BGB) & 150 & 6.10 \\
Branch biomass (BrB) & 217 & 8.83 \\
Leaf biomass (LeB) & 236 & 9.6 \\
Stem biomass (SteB) & 254 & 10.33 \\
Total biomass (TB) & 244 & 9.93 \\
Twig biomass (TwB) & 121 & 4.92 \\
Others & 1,050 & 42.72 \\
Grand total & 2,458 & 100 \\
\hline
\end{tabular}

\subsection{Predictor variables}

Out of 2,458 equations, 1,500 were based on a single predictor. Diameter was the most widely used single predictor; 1,345 equations ( $55 \%$ of equations) were based on diameter. Height was used as single predictor in 74 equations (3\%), while wood density was the basis of only four equations. The combination of diameter and height was found in 873 equations, while diameter with wood density was observed in 50 equations. Only 14 equations used diameter, height, and wood density. The goodness-of-fit or the strength of the equations, expressed as $R^{2}$, was higher for diameter-height-wood density combinations (Fig. 2). The diameter-height combination showed higher variability in predictive power compared to diameter only equations, while the number of outliers and extreme $R^{2}$ values were higher in diameter alone equations. The $R^{2}$ value was greater than 0.7 in 1,582 equations and lower than 0.7 in 811 equations, while the remaining 65 equations did not specify the $R^{2}$ value.

\subsection{Species- vs. habitat-specific}

Twenty-one habitat types and 65 species were studied in detail. Species-specific studies contributed 1,947 equations, which was about $79 \%$ of the equations (Table 4 ). This included equations developed for 55 species, 8 genera (e.g., Shorea), and 2 groups (two species combined together as a group) (e.g., Avicennia marina and Rhizophora mucronata) which will be hereafter known as species-specific equations. Of these, 1,106 equations were for major biomass components such as AGB, BGB, TB, and so on, and 841 are for other category (Table 4). The most frequently studied biomass component was total

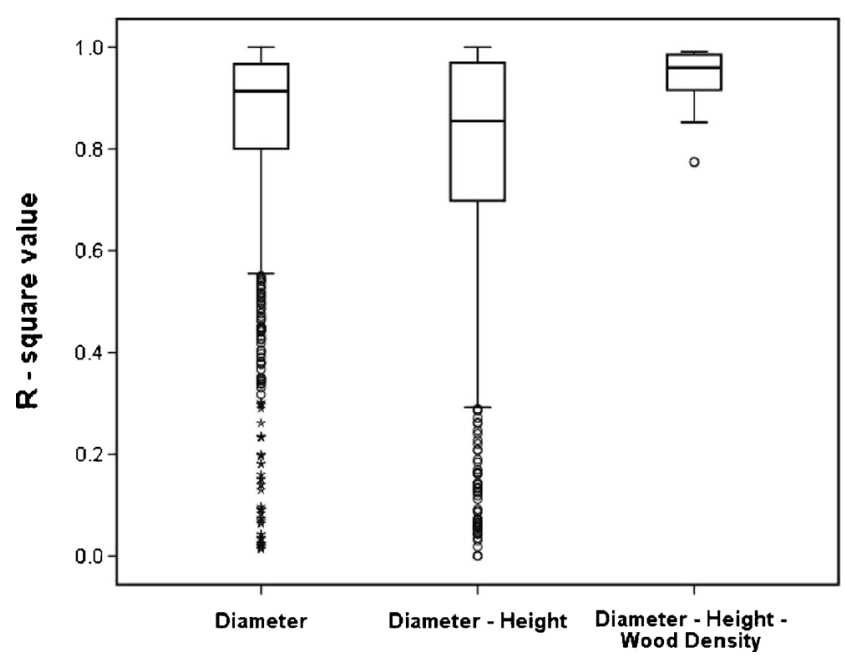

Fig. 2 The boxplot displays the variation in " $r^{2}$ " values for the biomass equations in Indonesia. The boxes indicate the interquartile range and encompass $50 \%$ of the data values. The error bars represent the 10 to $90 \%$ range of the values, and the open circles and asterisks indicate data points that are located at least 1.5 and 3 times away from the interquartile range, respectively 
Table 4 Number of biomass equations according to tree species and tree components

\begin{tabular}{|c|c|c|c|c|c|c|c|c|c|}
\hline No. & Species name & AGB & BGB & $\mathrm{BrB}$ & LeB & SteB & TB & TwB & Other \\
\hline 1 & Acacia auriculiformis & 1 & 1 & 1 & 1 & 1 & 0 & 0 & 5 \\
\hline 2 & Acacia crassicarpa & 12 & 4 & 16 & 16 & 17 & 4 & 15 & 133 \\
\hline 3 & Acacia mangium & 9 & 32 & 27 & 38 & 30 & 22 & 3 & 137 \\
\hline 4 & Agathis loranthifolia & 1 & 1 & 0 & 1 & 1 & 2 & 0 & 1 \\
\hline 5 & Aleurites moluccana & 1 & 0 & 0 & 0 & 0 & 1 & 0 & 0 \\
\hline 6 & Alphonsea sp. & 0 & 1 & 0 & 0 & 0 & 0 & 0 & 1 \\
\hline 7 & Avicennia marina & 3 & 3 & 0 & 0 & 0 & 4 & 0 & 0 \\
\hline 8 & Avicennia marina and Rhizophora mucronata & 1 & 0 & 0 & 0 & 0 & 0 & 0 & 0 \\
\hline 9 & Bruguiera gymnorrhiza & 1 & 0 & 0 & 0 & 0 & 0 & 0 & 0 \\
\hline 10 & Bruguiera parviflora & 0 & 0 & 1 & 1 & 1 & 0 & 0 & 1 \\
\hline 11 & Bruguiera sexangulata & 0 & 0 & 1 & 1 & 1 & 0 & 0 & 1 \\
\hline 12 & Bruguiera spp. & 0 & 3 & 3 & 2 & 3 & 2 & 2 & 14 \\
\hline 13 & Coffea arabica & 1 & 1 & 0 & 0 & 0 & 0 & 0 & 0 \\
\hline 14 & Dacryodes angulata & 0 & 1 & 0 & 0 & 0 & 0 & 0 & 1 \\
\hline 15 & Dalbergia latifolia & 1 & 1 & 1 & 1 & 1 & 0 & 0 & 5 \\
\hline 16 & Dehaasia sp. & 0 & 1 & 0 & 0 & 0 & 0 & 0 & 1 \\
\hline 17 & Dendrocalamus asper & 1 & 0 & 0 & 1 & 1 & 0 & 0 & 6 \\
\hline 18 & Dipterocarpus spp. & 3 & 0 & 0 & 0 & 0 & 0 & 0 & 0 \\
\hline 19 & Durio lowianus & 0 & 1 & 0 & 0 & 0 & 0 & 0 & 1 \\
\hline 20 & Elaeis guineensis & 8 & 0 & 0 & 0 & 0 & 0 & 0 & 0 \\
\hline 21 & Elmerrillia celebica & 0 & 1 & 1 & 1 & 1 & 1 & 1 & 10 \\
\hline 22 & Elmerrillia ovalis & 0 & 1 & 1 & 1 & 1 & 1 & 1 & 10 \\
\hline 23 & Eucalyptus (hybrid) & 0 & 0 & 0 & 0 & 0 & 34 & 0 & 0 \\
\hline 24 & Eucalyptus grandis & 1 & 5 & 8 & 8 & 8 & 7 & 0 & 4 \\
\hline 25 & Eucalyptus pellita & 0 & 0 & 0 & 0 & 0 & 0 & 0 & 6 \\
\hline 26 & Eucalyptus sp. & 0 & 0 & 0 & 0 & 0 & 2 & 0 & 0 \\
\hline 27 & Eucalyptus urograndis & 0 & 0 & 4 & 4 & 0 & 0 & 4 & 8 \\
\hline 28 & Eucalyptus urophylla & 0 & 1 & 1 & 1 & 1 & 1 & 0 & 5 \\
\hline 29 & Eugenia sp. & 0 & 1 & 0 & 0 & 0 & 0 & 0 & 1 \\
\hline 30 & Ficus sp. & 2 & 0 & 0 & 0 & 0 & 0 & 0 & 0 \\
\hline 31 & Geunsia pentandra & 2 & 0 & 0 & 0 & 0 & 0 & 0 & 0 \\
\hline 32 & Gigantochloa apus & 0 & 0 & 0 & 1 & 1 & 1 & 1 & 6 \\
\hline 33 & Gliricidia sepium & 0 & 2 & 1 & 1 & 1 & 0 & 0 & 18 \\
\hline 34 & Gmelina arborea & 0 & 0 & 1 & 1 & 1 & 0 & 0 & 5 \\
\hline 35 & Gonystylus bancanus & 0 & 0 & 2 & 2 & 2 & 0 & 2 & 2 \\
\hline 36 & Hevea brasiliensis & 3 & 0 & 2 & 2 & 2 & 17 & 0 & 25 \\
\hline 37 & Hopea spp. & 3 & 0 & 0 & 0 & 0 & 0 & 0 & 0 \\
\hline 38 & Intsia spp. & 4 & 0 & 0 & 0 & 0 & 0 & 0 & 0 \\
\hline 39 & Lantana camara & 0 & 1 & 0 & 1 & 1 & 0 & 0 & 5 \\
\hline 40 & Macaranga gigantea & 0 & 0 & 1 & 1 & 1 & 0 & 0 & 0 \\
\hline 41 & Macaranga gigantea and Macaranga hypoleuca & 1 & 0 & 0 & 0 & 0 & 0 & 0 & 0 \\
\hline 42 & Mellaleuca cajuputi & 0 & 0 & 0 & 0 & 1 & 1 & 0 & 7 \\
\hline 43 & Musa $\times$ paradisiaca & 1 & 0 & 0 & 0 & 0 & 0 & 0 & 0 \\
\hline 44 & Myristica sp. & 0 & 1 & 0 & 0 & 0 & 0 & 0 & 1 \\
\hline 45 & Nypa fruticans & 0 & 0 & 0 & 7 & 7 & 7 & 0 & 63 \\
\hline 46 & Palaquium sp. & 0 & 1 & 0 & 0 & 0 & 0 & 0 & 1 \\
\hline 47 & Palaquium spp. & 3 & 0 & 0 & 0 & 0 & 0 & 0 & 0 \\
\hline 48 & Paraserianthes falcataria & 7 & 7 & 10 & 10 & 10 & 13 & 6 & 51 \\
\hline 49 & Pinus merkusii & 15 & 17 & 20 & 11 & 23 & 28 & 8 & 29 \\
\hline
\end{tabular}


Table 4 (continued)

\begin{tabular}{|c|c|c|c|c|c|c|c|c|c|}
\hline No. & Species name & AGB & BGB & $\mathrm{BrB}$ & LeB & SteB & TB & TwB & Other \\
\hline 50 & Piper aduncum & 2 & 0 & 0 & 0 & 0 & 0 & 0 & 0 \\
\hline 51 & Pometia spp. & 4 & 0 & 0 & 0 & 0 & 0 & 0 & 0 \\
\hline 52 & Rhizophora apiculata & 8 & 9 & 16 & 16 & 16 & 7 & 14 & 46 \\
\hline 53 & Rhizophora spp. & 0 & 1 & 1 & 0 & 1 & 3 & 0 & 1 \\
\hline 54 & Rhizopora mucronata & 0 & 4 & 4 & 4 & 4 & 4 & 2 & 38 \\
\hline 55 & Scaphium macropodum & 0 & 1 & 0 & 0 & 0 & 0 & 0 & 1 \\
\hline 56 & Schima wallichii & 0 & 0 & 24 & 24 & 24 & 24 & 23 & 123 \\
\hline 57 & Shorea dasyphylla & 0 & 1 & 0 & 0 & 0 & 0 & 0 & 1 \\
\hline 58 & Shorea leprosula & 1 & 0 & 5 & 0 & 12 & 9 & 0 & 4 \\
\hline 59 & Shorea spp. & 3 & 0 & 0 & 0 & 0 & 0 & 0 & 0 \\
\hline 60 & Swietenia macrophylla & 10 & 2 & 10 & 10 & 10 & 1 & 9 & 16 \\
\hline 61 & Swietenia mahagonii & 1 & 0 & 1 & 1 & 1 & 0 & 0 & 5 \\
\hline 62 & Tectona grandis & 8 & 9 & 11 & 11 & 11 & 10 & 0 & 41 \\
\hline 63 & Theobroma cacao & 1 & 0 & 0 & 0 & 0 & 0 & 0 & 0 \\
\hline 64 & Vatica sumatrana & 0 & 1 & 0 & 0 & 0 & 0 & 0 & 1 \\
\hline \multirow[t]{2}{*}{65} & Xylocarpus granatum & 4 & 0 & 4 & 4 & 4 & 0 & 4 & 0 \\
\hline & Grand total & 127 & 116 & 178 & 184 & 200 & 206 & 95 & 841 \\
\hline
\end{tabular}

Abbreviations are detailed in Table 3

biomass (206) followed by stem biomass (200), leaf biomass (184), branch biomass (178), aboveground biomass (127), belowground biomass (116), and twig biomass (95). Although 65 species were studied, AGB, BGB, and total biomass were reported only for 34,31 , and 25 species, respectively.

Out of the 1,947 species-specific equations, seven species contributed 1,255 allometric equations (65\%). This includes Acacia mangium (298), Schima wallichii (242), Acacia crassicarpa (217), Pinus merkusii (151), Rhizophora apiculata (132), Paraserianthes falcataria (114), and Tectona grandis (101). The highest number of biomass equations was observed for A. mangium for different categories such as BGB (32), branch biomass (27), leaf biomass (38), stem biomass (30), and others (137). For AGB, total biomass, and twig biomass, the most frequently studied species include P. merkusii, Eucalyptus hybrid, and S. wallichii with 15, 34, and 23 equations, respectively.

We found 511 habitat-specific equations ( $21 \%$ of the equations). Among these, 302 equations were for major biomass components and 209 were for the other category. Aboveground biomass, belowground biomass, and total biomass had 59, 34, and 38 equations, respectively. About 21 different habitats and/or management units were specified in these studies (Table 5). We have refined these 21 categories into six major forest types (Table 6). We focus only on AGB, BGB, and TB equations as these equations refer to the major biomass pools, which reduced the number of equations from 511 to 131. Dipterocarp forest and peat swamp forest contributed 43 and $24 \%$ of the total with 56 and 31 equations, respectively. Heath forest, limestone forest, and mangrove forest were represented but with three or fewer equations each. However, $28 \%$ of the equations provided no detailed information on the forest types from which they were derived.

\subsection{Spatial distribution of allometric equations}

Most of the studies were carried out in Java, Kalimantan, and Sumatra islands (Fig. 3). Province-wise, the highest number of studies appeared in Central Java (28) followed by West Java (26) and East Kalimantan (20). A limited number of efforts were reported from provinces such as North Sulawesi (Langi 2007), Central Sulawesi (Massiri 2010), Papua (Maulana and Asmoro 2011a), West Papua (Maulana and Asmoro 2011b; Hendri et al. 2012), and Maluku (Stas 2011). We did not find any biomass equations from Bali, Lesser Sunda Islands, and Nusa Tenggara regions. Primary forest types, i.e., upland, peat swamp, and mangrove forests, were underexplored and represented a negligible fraction of the equations. The majority of the equations were from plantations crops and agroforestry systems. The research in Java mostly focused on plantation forests, while in Kalimantan and Sumatra, the focus was on secondary forest types.

\subsection{Validation of equations}

The MAPE for the lowland dipterocarp forests (LDF) ranged from 25 to $90 \%$. Seven LDF equations have MAPEs lower than $40 \%$, while others have departures more than $60 \%$. Most of inaccurate equations were developed from a small number or sample and/or a limited DBH range. LDF2 equation is the 
Table 5 Number of biomass equations as per habitat and/or management unit wise

\begin{tabular}{|c|c|c|c|c|c|c|c|c|c|}
\hline No. & Habitat & AGB & BGB & $\mathrm{BrB}$ & LeB & SteB & TB & TwB & Others \\
\hline 1 & Community forest & 2 & 2 & & & & 4 & & 0 \\
\hline 2 & Dipterocarp forest & 7 & 6 & & & & & & 6 \\
\hline 3 & Dryland forest & & & & & & 1 & & 0 \\
\hline 4 & Heath forest & 3 & & 4 & 5 & 5 & & 3 & 15 \\
\hline 5 & Lowland evergreen dipterocarp forest & 1 & & 2 & 4 & 5 & & & 1 \\
\hline 6 & Lowland mixed dipterocarp forest & 6 & & & & & & & 0 \\
\hline 7 & Managed mixed dipterocarp Forest & 1 & 4 & 1 & 1 & 5 & 1 & & 7 \\
\hline 8 & Mangrove forest & 1 & & & 1 & 1 & 1 & & 1 \\
\hline 9 & Mixed dipterocarp forest & 6 & 6 & 4 & 4 & 4 & 7 & 0 & 26 \\
\hline 11 & Plantation forest & & & & & & 3 & & 0 \\
\hline 10 & Primary peat swamp forest & 2 & 5 & 11 & 11 & 11 & 14 & 11 & 18 \\
\hline 12 & Secondary dipterocarp forest & 2 & & & & & 2 & & \\
\hline 13 & Secondary forest & 7 & 2 & 4 & 4 & 4 & 1 & 2 & 21 \\
\hline 14 & Secondary lowland dipterocarp forest & 1 & & & & & & & 0 \\
\hline 15 & Secondary lowland limestone forest & 2 & & & & & & & 0 \\
\hline 16 & Secondary mixed forests & 3 & 2 & 1 & 1 & 1 & 0 & 0 & 5 \\
\hline 17 & Secondary mixed dipterocarp forest & 1 & 4 & 2 & 2 & 4 & 1 & & 13 \\
\hline 18 & Secondary peat swamp forest & 10 & & 10 & 10 & 10 & & 10 & 75 \\
\hline 19 & Swidden-land forest & & & & 3 & 1 & & & 3 \\
\hline 20 & Tropical forest & & 3 & & 3 & 3 & 3 & & 18 \\
\hline \multirow[t]{2}{*}{21} & Upland forest & 3 & & & & & & & 0 \\
\hline & Total & 58 & 34 & 39 & 49 & 54 & 38 & 26 & 209 \\
\hline
\end{tabular}

Abbreviations are detailed in Table 3

best equation with the lowest MAPE (Table 7) and with a mean distribution of MPE close to zero (Fig. 4). It was developed from 40 samples and a maximum DBH of $115 \mathrm{~cm}$ (Anggraini 2011). Compare to LDF equations, the peat swamp forest (PSF) equations have lower variations in MAPEs, which range from 17 to $55 \%$ (Table 7). The best PSF equation was PSF6 developed from a high DBH range with a relatively small number of samples (Manuri et al. 2013). Other PSF equations were developed with maximum DBH of less than $72 \mathrm{~cm}$. All MPE distributions from the best equations had a trending line that was close to zero (Figs. 4 and 5).

Table 6 The availability of aboveground, belowground, and total biomass equations with respect to major forest types in Indonesia

\begin{tabular}{llllll}
\hline No. & Forest types & AGB & BGB & TB & Total \\
\hline 1 & Dipterocarp forest & 25 & 20 & 11 & 56 \\
2 & Heath forest & 3 & - & - & 3 \\
3 & Limestone forest & 2 & - & - & 2 \\
4 & Mangrove forest & 1 & - & 1 & 2 \\
5 & Peat swamp forest & 12 & 5 & 14 & 31 \\
6 & Other forest & 16 & 9 & 12 & 37 \\
& Grand total & 59 & 34 & 38 & 131 \\
\hline
\end{tabular}

\subsection{Other ancillary information}

Apart from the biomass equations, the survey attempted to collect available information on wood density, biomass expansion factors and root/shoot ratios. The survey compiled 184 wood density values that included 113 species from 15 studies. This covered different vegetation types such as peat swamp forest (76 species), lowland mixed dipterocarp forest (10 species), mangroves (10 species), mixed secondary forest ( 9 species), plantation species ( 6 species), and other forest species ( 2 species). The wood density values varied from $290 \mathrm{~kg} / \mathrm{m}^{3}$ for Ficus spp. in peat swamp forest to 1, $240 \mathrm{~kg} / \mathrm{m}^{3}$ in $R$. apiculata in mangroves. In general, mangrove forest showed high average wood density followed by peat swamp and dipterocarp forests (Fig. 6). Information on biomass expansion factors and root/shoot ratios was relatively small. We found 22 biomass expansion factors (7 species from 11 studies), mostly from plantations. Biomass expansion factors ranged from 1.09 for $R$. apiculata to 4.84 for $T$. grandis. The study compiled 25 root/shoot ratios (four species from eight studies) from different plantations with values ranging from 0.05 to 12.7 . The lowest root/shoot ratios were observed for $T$. grandis and the highest were for P. falcataria (ESM 4 and 5). 


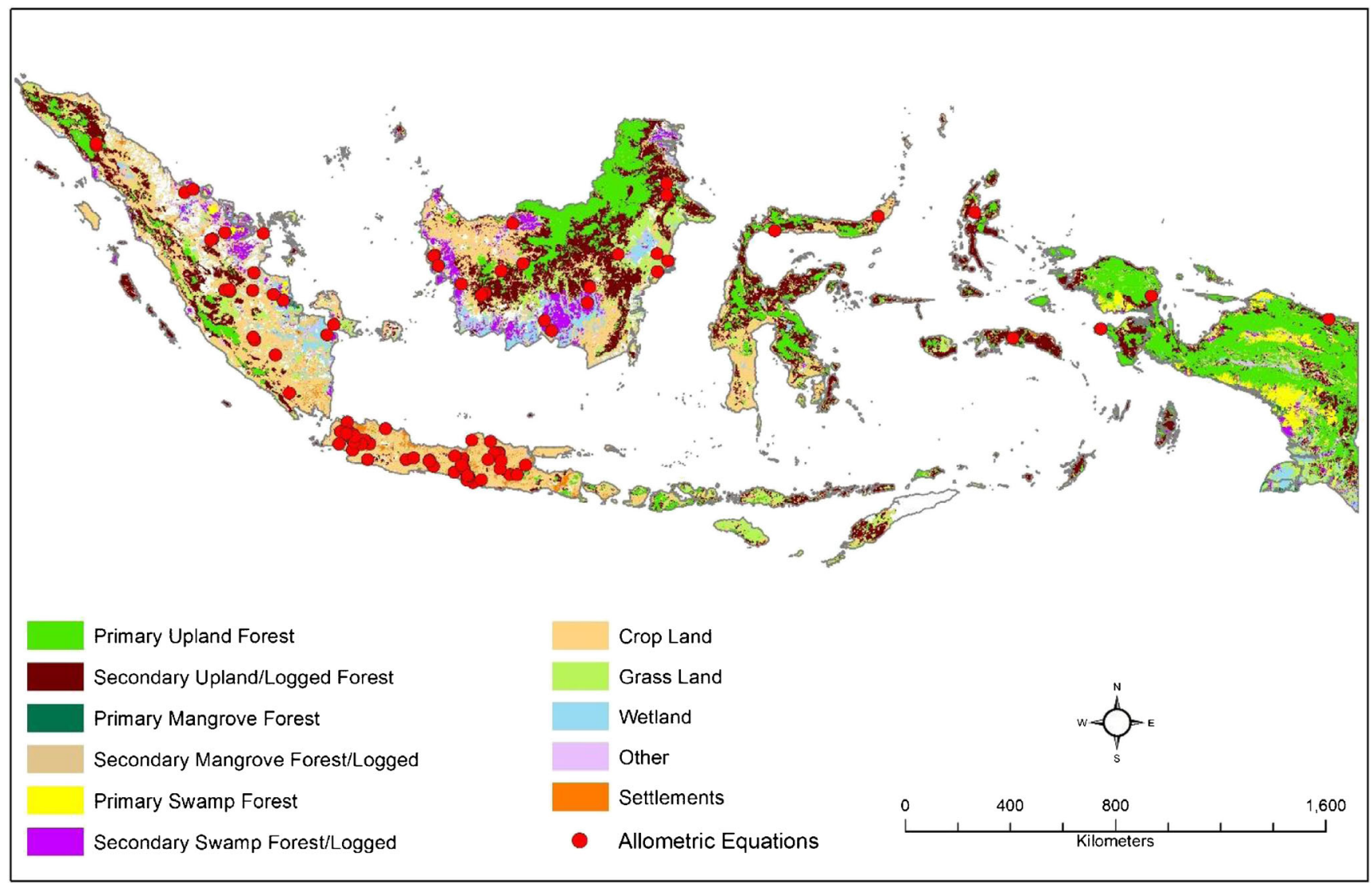

Fig. 3 Spatial distribution of allometric equations in Indonesia. The base land use/land cover map was prepared from Landsat series data by the Ministry of Forestry, Government of Indonesia. The classes in the base map were recoded to reflect the IPCC land cover classes

\section{Discussion}

\subsection{Comparison with previous work}

In Indonesia, Krisnawati et al. (2012) published a major compilation of equations that included 437 biomass allometric equations and 370 volume equations. These authors also reported 193 studies in Indonesia; of these, $58 \%$ developed volume equations and the rest (81 studies) developed allometric equations. Our study recorded 168 references only for biomass allometric equations. Masripatin et al. (2010) estimated the carbon stock of Indonesia using 38 equations that included 11 equations in natural forests, 19 equations in plantations, and 8 equations in agroforestry systems. Other notable efforts in Indonesia include the work carried out by Hairiah and Rahayu (2007), Sutaryo (2009), and Hairiah et al. (2010) that presented methods and protocols for biomass measurements, with a list of important equations. The language used in most of the above works was Bahasa Indonesia, so most equations are not readily accessible to international peers.

\subsection{Data sources}

Our review shows that the availability of allometric equations is high in Indonesia (2,458 equations) compared to sub-

Table 7 Mean percentage error (MPE) and mean absolute percentage error (MAPE) of the model estimates using the select allometric equations given in Table 2 for calculating the biomass

\begin{tabular}{|c|c|c|c|c|c|c|c|c|c|c|c|c|}
\hline & LDF1 & LDF2 & LDF3 & LDF4 & LDF5 & LDF6 & LDF7 & LDF8 & LDF9 & LDF10 & LDF11 & LDF12 \\
\hline MPE & -81.55 & -3.99 & 13.09 & -90.46 & -32.90 & -88.79 & -11.87 & 0.66 & 56.13 & -37.42 & -92.64 & 6.12 \\
\hline \multirow[t]{2}{*}{ MAPE } & 81.57 & 25.23 & 35.56 & 90.46 & 34.34 & 88.79 & 34.69 & 37.25 & 67.95 & 37.93 & 92.64 & 32.29 \\
\hline & PSF1 & PSF2 & PSF3 & PSF4 & PSF5 & PSF6 & PSF7 & & & & & \\
\hline MPE & 6.78 & -4.22 & 23.87 & -5.004 & 49.94 & -5.98 & -13.59 & & & & & \\
\hline MAPE & 31.85 & 29.33 & 38.32 & 29.01 & 55.71 & 17.67 & 27.32 & & & & & \\
\hline
\end{tabular}

The lowest MAPE is given bold letters to specify the best equations in the respective group 

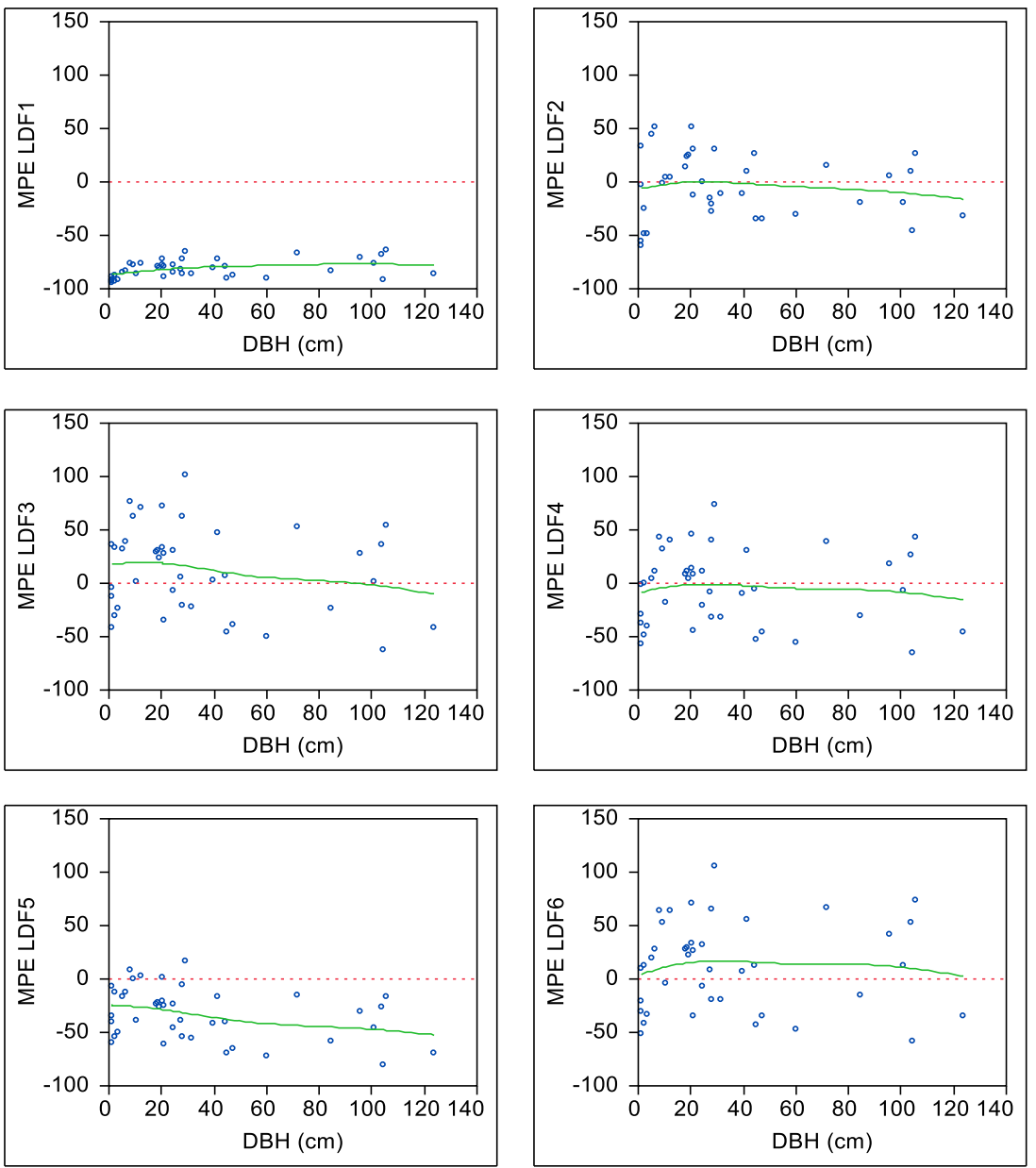

Fig. 4 Distribution of mean percentage errors $(M P E)$ in calculating aboveground biomass (AGB) for selected lowland dipterocarp forest equations (LDF1-12). For the equations, please refer Table 2

Saharan Africa (850 equations; Henry et al. 2011) and Europe (607 equations; Zianis et al. 2005). The majority of the information on allometric equations in Indonesia exists as grey literature in various university libraries. For example, we found $78 \%$ of the allometric equations in university libraries in the form of theses. In sub-Saharan Africa, the contribution from grey literature was about $72 \%$ (Henry et al. 2011). Apart from three theses written in English (Samalca 2007; Persch 2010; Stas 2011), all others were in Bahasa Indonesia. We contacted 63 experts and received responses from 54 of them; we might have missed a minor portion of the grey literature produced by remotely located universities.

\subsection{Sampling and parameters used for developing the equation}

The studies compiled during the present survey were based on a sample size ranging from 4 to 226 . Only a few studies cut more than 100 trees in Indonesia (Yamakura et al. 1986a, b; Hashimoto et al. 2004; Heriansyah et al. 2007; Miyamoto et al. 2007; Basuki et al. 2009; Hendri et al. 2012). The cumulative number of trees cut from 168 studies was 5,207 trees. This number outweighs all other studies in the tropics. For example, the most comprehensive pantropical study used only 2,410 trees (Chave et al. 2005) that is less than half of the trees cut in Indonesia alone. This underlines the importance of pooling the data and making it available for the wider scientific community for further testing and development of new models.

Allometric databases from African and European regions showed that diameter is the most common predictor of biomass (63 and $46 \%$, respectively). Our review also indicated that diameter is the most commonly used single predictor of biomass and $55 \%$ of the equations were based on it. This is probably because it can be measured easily and accurately in the field. The studies by Brown (2002) and Gibbs et al. (2007) also point out that the diameter alone can explain $95 \%$ of the variation in biomass in tropical mixed forest.

Although diameter was the most widely used predictor of aboveground biomass, caution should be applied when using such equations. A comparative study carried out by Harja et al. (2011) using the equations from Chave et al. (2005), 

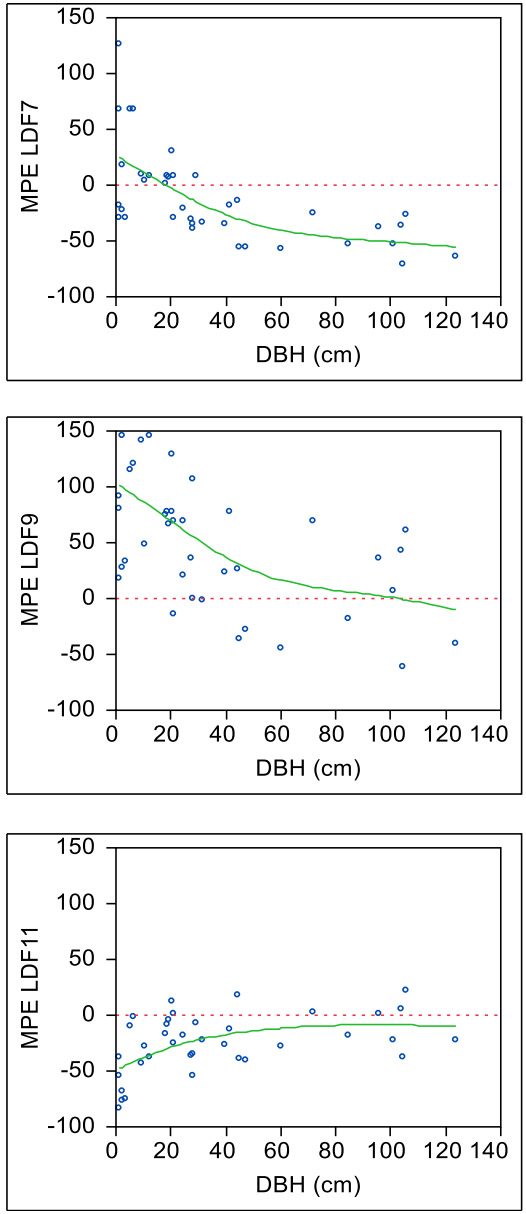

Fig. 4 (continued)

Brown et al. (1989), Basuki et al. (2009), and Ketterings et al. (2001) showed that all the equations performed equally well at the lower diameter range below $60 \mathrm{~cm}$, while three equations (except Chave's) overestimated the biomass above $60 \mathrm{~cm}$. Among these, Kettering's equation showed the highest level of overestimation due to the lower diameter of the data sets and the fact that the equation was locally developed for Jambi area. Many equations have limited applicability as many of these are derived from local studies and from a limited diameter range. We found eight studies with a high diameter range of $>100 \mathrm{~cm}$. Among these, Basuki et al. (2009) developed equations for the largest diameter range, from 5 to $200 \mathrm{~cm}$ for lowland mixed dipterocarp forest. Other studies that harvested trees with a diameter $>100 \mathrm{~cm}$ were Dharmawan and Samsoedin (2010) (119 cm), Marimpan (2010) (127.4 cm), Anggraeni (2011) (115 cm), Manuri et al. $(2011,2013)(102.9,117,172 \mathrm{~cm})$, Niapele (2011) $(115 \mathrm{~cm})$, Yeza (2012) $(118 \mathrm{~cm})$, and Yunianto (2012) $(115 \mathrm{~cm})$. As many as 40 studies in our database did not indicate the diameter range sampled.

Many authors argue about the various parameters to be taken into account for biomass estimation. According to Chave et al. (2005), the biomass of the tree can be predicted
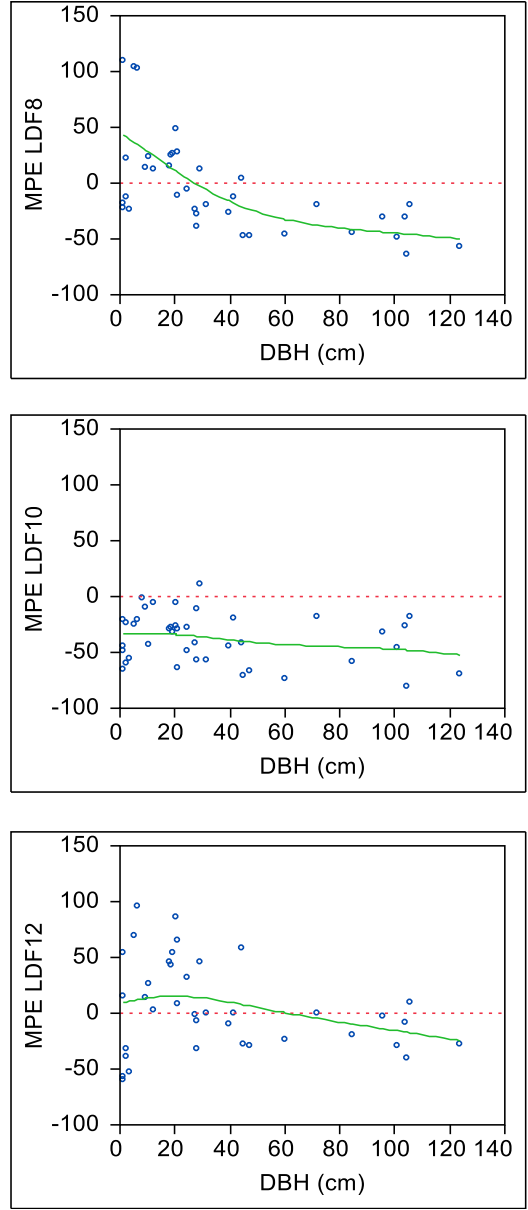

in order of importance using diameter, wood density, height, and forest type. Brown et al. (1989) supported the use of height and stratifying equations by climatic zones. Analysis by Feldpausch et al. (2012) shows that the integration of height into biomass estimates reduced estimates of tropical carbon storage by $13 \%$. However, several other authors have warned against including using height in regression equations (Overman et al. 1994; Leuschner et al. 2007). In a recent study in southwestern Amazon, Goodman et al. (2014) found that models without height overestimated AGB, but models that included height underestimated AGB substantially. Similarly in Indonesia, Basuki et al. (2009) noted that adding height into allometric equations did not increase the accuracy of the estimation. Moreover, measuring height of trees accurately in tropical dense forest is difficult. This suggests that models with only diameter and wood density may be more universal than models with diameter, wood density, and height. Basuki et al. (2009) also noted that use of diameter and wood density considerably increased the prediction capacity for a generalized/mixed species stand. Although wood density can increase the prediction capacity, only a limited number of the equations $(>3 \%)$ used wood density in our review. Perhaps, the increased availability of wood density values by the recent 
Fig. 5 Distribution of mean percentage errors $(M P E)$ in calculating aboveground biomass (AGB) for selected peat swamp forest equations (PSF1-7). For the equations, please refer Table 2
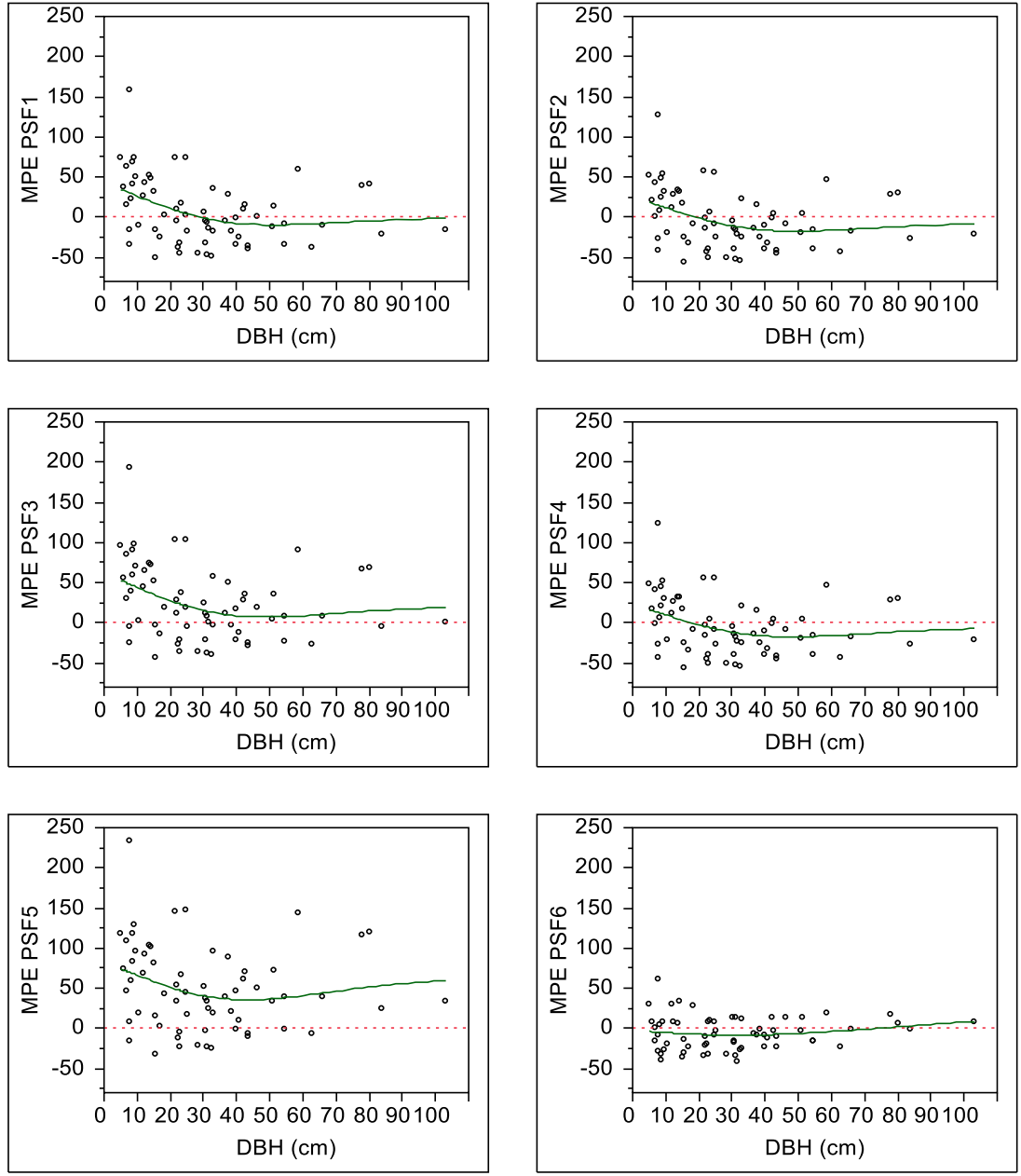

compilations such as Zanne et al. (2009) and ICRAF's wood density databases (available from http://db.worldagroforestry. $\mathrm{org} / \mathrm{wd}$ ) may enhance the quality of future biomass research.

\subsection{Distribution of the equations in different provinces and islands}

There was a clear deficiency of available data in many regions. Most of the studies were focused on Java, Kalimantan, and Sumatra. Islands such as Sulawesi, Papua, Maluku, Bali, Lesser Sunda, and Nusa Tenggara regions were understudied or unexplored. Krisnawati et al. (2012) also reported the lack of sufficient biomass research in the eastern Indonesian region including Sulawesi, Maluku, Nusa Tenggara, and Papua. This is a serious concern as these islands are placed on the other side of the Wallace line. Biogeographically, the Wallace line separates Indonesian islands into Indo-Malayan (western side) and Australasian (eastern side) (Wallace 1869; Whitmore 1982). A wide range of distinctive ecosystem types are reported on the eastern side, which are different to those found on the western side. For example, Cannon et al. (2007) classified 18 ecosystem and vegetation types in Sulawesi. Our survey did not come across any studies in these ecosystem types, except one from lowland limestone forest (Stas 2011) that was farther east of 
Fig. 6 Average wood density of major vegetation types in Indonesia. The small square in the middle of each error bar represents the mean wood density, and the attached bars are the upper and lower limits for the $95 \%$ confidence interval band on the sample mean

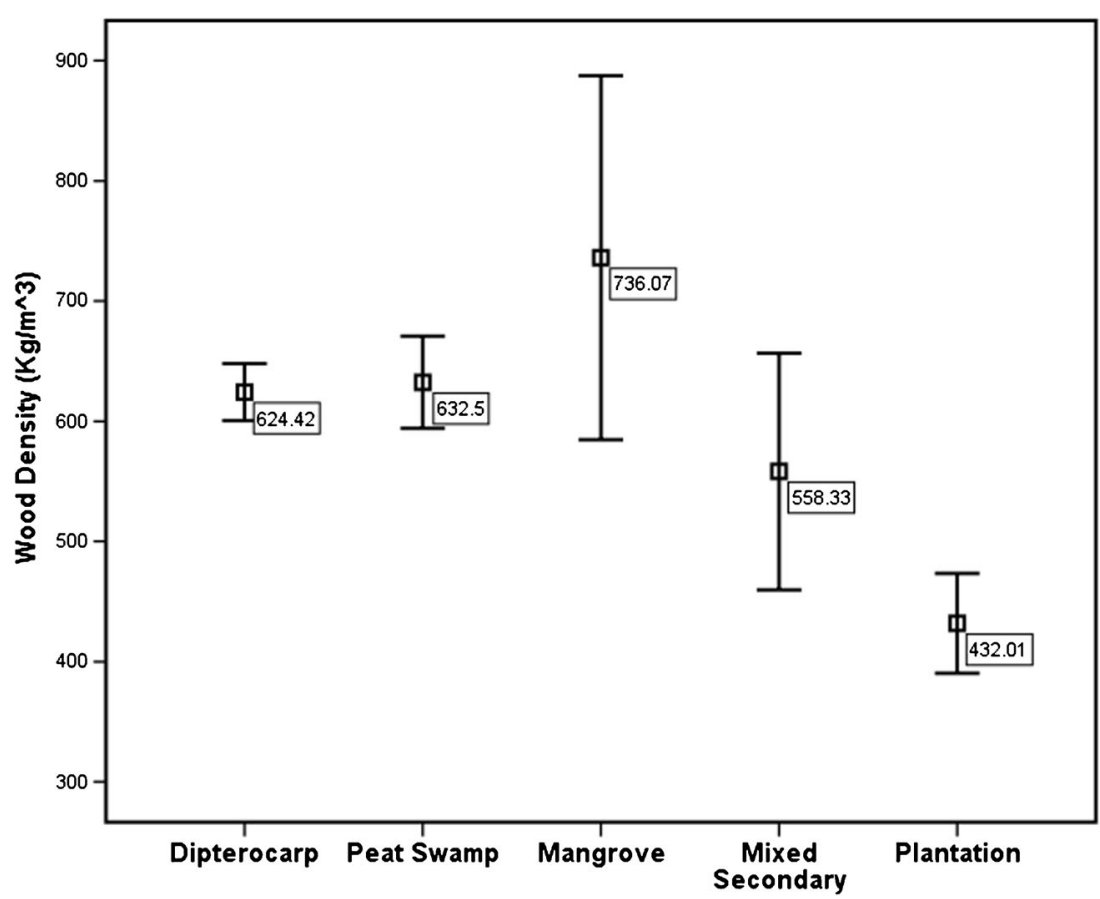

Sulawesi Island. Similarly, Marshall and Beehler (2007) identified ten forest types in Papua: mangrove forest, swamp, swamp brush, swamp forest, lowland evergreen forest, lower montane rainforest, upper montane rain forest, subalpine forest, brush, and savanna. Among these, lowland evergreen forest was studied by Hendri et al. (2012) and claimed to be first of its kind from the Sahul shelf of the Australian and New Guinea continent in Papua. This highlights the need for more research on the unique ecosystems of these islands.

\subsection{Distribution of the equations with respect to different forest types}

Forest and vegetation classification of Indonesia has been developed by van Steenis (1957), adapted by Whitmore (1984) and further refined by Kartawinata et al. (1989) based on climate, altitude, soil, and hydrology aspects. As per this classification, Indonesia harbors 14 different forest types (Kartawinata et al. 1989). However, Monk et al. (1997) observe that this classification system was not good enough to apply for the lesser Sunda region which has smaller islands, a seasonal climate, and holds moist deciduous, dry deciduous, thorn, and dry evergreen forests. Similarly, mangrove forest in the Indonesian archipelago is further subdivided into coastal, estuarine, and riverine types, which have different species composition and biomass stocks. In another case, heath forest grows on siliceous, sand-dominated soils that are relatively nutrient-poor and highly acidic, with a single layer of very dense saplings and poles. In a more suitable environment, this forest could grow like lowland dipterocarp forest with trees reaching around $30 \mathrm{~m}$ in height (MacKinnon et al. 1996).
Therefore, further biomass studies on specific forest types that represent major islands will reduce the uncertainty of biomass estimation in Indonesia.

In our survey, we found that secondary lowland dipterocarp and peat swamp forests were the most studied forest types in Indonesia. Large areas of lowland dipterocarp and peat swamp forests in Indonesia have been allocated for timber concessions. Timber concessions could provide better access to forest stands and permit cutting and measuring of trees. The studies in Java are mostly in plantation forests of "Perhutani, " a state-owned plantation company operating in Java. In contrast, few equations were developed in primary forests, and this is probably due to limited forest concessions in these forest types. Some studies have been also conducted in community lands or forests, which require less bureaucratic procedures to obtain a research permit (Ketterings et al. 2001).

In our survey, we found very few biomass equations developed for freshwater swamp forests on mineral soils, ultramafic forests, and seasonal forests. Biomass studies of lowland tropical forests in Sulawesi, Maluku, and Papua would also be important to fill data gaps. These areas are remote and pose logistical challenges for research. Other important gaps are in lowland forests in Java and freshwater swamp forests on mineral soils in Sumatra and Kalimantan, which are experiencing rapid deforestation.

Finally, many authors provided insufficient information on the forest types studied. Instead of describing the forest types, some authors used the terms for land use category or successional stage such as community forest, swidden forest, or secondary regrowth. Improving the descriptions of methods and forest types will make these studies more useable. 


\subsection{The accuracy of the equations}

Our effort to validate equations was challenged by the availability of the destructive sample data sets. Moreover, validating all of the equations is beyond the scope of the present review. The validation exercise carried out here indicates that those who would like to use our database should perform quality checks and validation before they use these equations for biomass estimation. Our validation efforts show that peat swamp forests have error departures of less than $20 \%$, while the allometric models from lowland dipterocarp forest have larger errors. This may be related to the extremely high variability of biomass in large trees (Manuri et al. 2014). It is therefore important to select equations developed from a large sample size that covers a wide range of DBH. Of the validated 19 equations, the best estimation of the biomass was shown by Anggraeni et al. (2011) in lowland dipterocarp forest and by Manuri et al. (2012) in peat swamp forest. Among these, Anggraeni's work was an unpublished thesis, indicating the importance of grey literature available at universities and the need for a common platform for sharing this kind of data and results.

\section{Conclusions and future considerations}

Our review contains a comprehensive collection of biomass equations for Indonesia. The equations represent a wide variety of forest types and species. The review shows that large amount of data exists to support development of biomass equations in Indonesia. It also shows that biomass equation availability is skewed to certain regions, species, and habitats. Java and Kalimantan have the largest number of studies and seven species contributed more than half the biomass equations. We also observed that specific biomass components were given preference in the literature. In many cases, sample size was inadequate and diameter ranges were limited, which limits the applicability of these equations.

In order to improve the biomass research in the country, a wide range of such issues need to be addressed. Studies need to provide clear definitions of the biomass compartments and forest types. The studies restricted to minor biomass compartments (such as leaf and fruit) have limited use in the context of climate change mitigation as they do not cover large carbon pools of the system. The increase in sample size and the inclusion of trees that span large diameter ranges can reduce the error in the biomass estimates and make equations more generally applicable. The procedures followed during the data collection and analysis should be given in detail, and original data sets should be made available within publications. The allometric models should be developed using a step-wise approach, and the percentage contribution of each variable to the overall model fitting should be specified.
This compilation is a contribution to support the readiness activities of national-level climate change mitigation projects and programs including REDD+. Further research is required to analyze the quality and performance of the equations under a wider range of conditions. This analysis also highlights important gaps and the need for new equations, particularly for primary forests and swamp forests on mineral soils.

Acknowledgments This study is part of a larger research program entitled as "Global Comparative Study on REDD+" run by the Center for International Forestry Research with financial support from NORAD (Grant Agreement no. QZA-10/0468) and AusAID (Grant Agreement no. 46167). The work was conducted as part of the CGIAR Research Program on Forests, Trees and Agroforestry. We would like to acknowledge the 54 experts who responded to our survey and shared key information about their biomass research in Indonesia. We would like to acknowledge Oktarita Satria, Ajeng Miranti Putri, and Choiriatun Nur Annisa for their assistance with the data collection, Aneesh Anandadas for GIS analysis, and Arief Wijaya, Daniel Murdiyarso, Haruni Krisnawati, Joko Purbopuspito, Kristell Hergoualc'h, Kuswata Kartawinata, Markku Kanninen, Peter Kanowski, Sonya Dewi, and Yves Laumonier for valuable and beneficial discussions. We greatly appreciate the comments of the reviewers and the editor that have substantially enhanced the quality of the manuscript.

Open Access This article is distributed under the terms of the Creative Commons Attribution 4.0 International License (http:// creativecommons.org/licenses/by/4.0/), which permits unrestricted use, distribution, and reproduction in any medium, provided you give appropriate credit to the original author(s) and the source, provide a link to the Creative Commons license, and indicate if changes were made.

\section{References}

Achard F, Eva HD, Stibig H-J, Mayaux P, Gallego J, Richards T, Malingreau J-P (2002) Determination of deforestation rates of the world's humid tropical forests. Science 29:999-1002

Alvarez E, Rodríguez L, Duque A, Saldarriaga J, Cabrera K, de las Salas G, del Valle I, Lema A, Moreno F, Orrego S, Rodriguez L (2012) Tree above-ground biomass allometries for carbon stocks estimation in the natural forests of Colombia. For Ecol Manag 267:297-308

Anggraeni WB (2011) Model Pendugaan Cadangan Biomassa dan Karbon Hutan Tropis Basah PT Sari Bumi Kusuma, Kalimantan Tengah. Unpublished postgraduate thesis, Universitas Gadjah Mada, Indonesia

Basuki TM, van Laake PE, Skidmore AK, Hussain YA (2009) Allometric equations for estimating the above-ground biomass in tropical lowland dipterocarp forests. For Ecol Manag 257:1684-1694

Bonan GB (2008) Forests and climate change: forcings, feedbacks, and the climate benefits of forests. Science 320:1444-1449

Brown S (1997) Estimating biomass and biomass change of tropical forests: a primer (FAO Forestry Paper - 134). Food and agriculture organization of the United Nations, Rome

Brown S (2002) Measuring carbon in forests: current status and future challenges. Environ Pollut 116:363-372

Brown S, Gillespie AJR, Lugo AE (1989) Biomass estimation methods for tropical forests with applications to forest inventory data. For Sci 35:881-902 
Cannon CH, Summers M, Harting JR, Kessler PJA (2007) Developing conservation priorities based on forest type, condition, and threats in a poorly known ecoregion: Sulawesi, Indonesia. Biotropica 39:747759. doi:10.1111/j.1744-7429.2007.00323.x

Chave J, Andalo C, Brown S, Cairns MA, Chambers JQ, Eamus D, Folster H, Fromard F, Higuchi N, Kira T, Lescure JP, Nelson BW, Ogawa H, Puig H, Riera B, Yamakura T (2005) Tree allometry and improved estimation of carbon stocks and balance in tropical forests. Oecologia 145:87-99

Dharmawan IWS, Samsoedin I (2010) Dinamika Potensi Biomassa Karbon Pada Lanskap Hutan Bekas Tebangan. Jurnal Penelitian Hutan. Pusat Penelitian Hutan dan Konservasi Alam. Bogor. Manuscript

Eamus D, McGuinness K, Burrows W (2000) Review of allometric relationships for estimating woody biomass for Queensland, the northern territory and western Australia. National Carbon Accounting System Technical Report, No. 5a. ISSN 14426838

Enquist BJ, West GB, Charnov EL, Brown JH (1999) Allometric scaling of production and life-history variation in vascular plants. Nature 401:907-911

FAO (2010) Global forest resources assessment 2010. Food and Agricultural Organization of the United Nations, Rome

Fayolle A, Doucet J-L, Gillet J-F, Bourland N, Lejeune P (2013) Tree allometry in Central Africa: testing the validity of pantropical multispecies allometric equations for estimating biomass and carbon stocks. For Ecol Manag 305:29-37

Febrina Y (2012) Pendugaan potensi biomassa dan karbon di atas permukaan tanah pada empat kondisi hutan gambut di areal IUPHHK-HA PT diamond raya timber. Unpublished undergraduate thesis, Institut Pertanian Bogor, Indonesia

Feldpausch TR, Lloyd J, Lewis SL, Brienen RJW, Gloor M, Monteagudo Mendoza A, Lopez-Gonzalez G, Banin L, Abu Salim K, AffumBaffoe K, Alexiades M, Almeida S, Amaral I, Andrade A, Aragão LEOC, Araujo Murakami A, Arets EJMM, Arroyo L, Aymard GA, Baker TR, Bánki OS, Berry NJ, Cardozo N, Chave J, Comiskey JA, Alvarez E, de Oliveira A, Di Fiore A, Djagbletey G, Domingues TF, Erwin TL, Fearnside PM, França MB, Freitas MA, Higuchi N, Iida EHCY, Jiménez E, Kassim AR, Killeen TJ, Laurance WF, Lovett JC, Malhi Y, Marimon BS, Marimon-Junior BH, Lenza E, Marshall AR, Mendoza C, Metcalfe DJ, Mitchard ETA, Neill DA, Nelson BW, Nilus R, Nogueira EM, Parada A, Peh KSH, Pena Cruz A, Peñuela MC, Pitman NCA, Prieto A, Quesada CA, Ramírez F, Ramírez-Angulo H, Reitsma JM, Rudas A, Saiz G, Salomão RP, Schwarz M, Silva N, Silva-Espejo JE, Silveira M, Sonké B, Stropp J, Taedoumg HE, Tan S, ter Steege H, Terborgh J, TorelloRaventos M, van der Heijden GMF, Vásquez R, Vilanova E, Vos VA, White L, Willcock S, Woell H, Phillips OL (2012) Tree height integrated into pantropical forest biomass estimates. Biogeosciences 9:3381-3403

Gibbs HK, Brown S, Niles JO, Foley JA (2007) Monitoring and estimating tropical forest carbon stocks: making REDD a reality. Environ Res Lett 4:045023

Goodman RC, Phillips OL, Baker TR (2014) The importance of crown dimensions to improve tropical tree biomass estimates. Ecol Appl 24:680-698

Hairiah K, Rahayu S (2007) Pengukuran 'karbon tersimpan' di berbagai macam penggunaan lahan. World Agroforestry Centre - ICRAF, SEA Regional Office, University of Brawijaya, Unibraw, Bogor, $77 \mathbf{p}$

Hairiah K, Dewi S, Agus F, Velarde S, Ekadinata A, Rahayu S, van Noordwijk M (2010) Measuring carbon stocks across land use systems: a manual. World Agroforestry Centre (ICRAF), SEA Regional Office, Bogor, 155 p

Hansen MC, Potapov PV, Moore R, Hancher M, Turubanova SA, Tyukavina A, Thau D, Stehman SV, Goetz SJ, Loveland TR, Kommareddy A, Egorov A, Chini L, Justice CO, Townshend JRG
(2013) High-resolution global maps of 21st-century forest cover change. Science 342:850-853

Harja D, Dewi S, Heryawan FX, van Noordwijk M (2011) Forest carbonstock estimates based on national forest inventory data. ALLREDDI Brief 02. World Agroforestry Centre (ICRAF) Southeast Asia Program, Bogor, Indonesia

Harris NL, Brown S, Hagen SC, Saatchi SS, Petrova S, Salas W, Hansen MC, Potapov PV, Lotsch A (2012) Baseline map of carbon emissions from deforestation in tropical regions. Science 336:1573-1576

Hashimoto T, Tange T, Masumori M, Yagi H, Sasaki S, Kojima K (2004) Allometric equations for pioneer tree species and estimation of the aboveground biomass of a tropical secondary forest in East Kalimantan. Tropics 14:123-130

Hendri, Yamashita T, Kuntoro A, Soo Lee H (2012) Carbon stock measurements of a degraded tropical logged-over secondary forest in Manokwari Reu aryan regency, West Papua, Indonesia. Beijing Forestry University and Springer-Verlag Berlin Heidelberg 2012. For Stud China 14:8-19

Henry M, Besnard A, Asante WA, Eshun J, Adu-Bredu S, Valentini R, Bernoux M, Saint-André L (2010) Wood density, phytomass variations within and among trees, and allometric equations in a tropical rainforest of Africa. For Ecol Manag 260:1375-1388

Henry M, Picard N, Trotta C, Manlay RJ, Valentini R, Bernoux M, SaintAndré L (2011) Estimating tree biomass of sub-Saharan African forests: a review of available allometric equations. Silva Fenn Monogr 45:477-569

Henry M, Bombelli A, Trotta C, Alessandrini A, Birigazzi L, Sola G, Vieilledent G, Santenoise P, Longuetaud F, Valentini R, Picard N, Saint-André L (2013) GlobAllomeTree: international platform for tree allometric equations to support volume, biomass and carbon assessment. iFor Biogeosci For 6:326-330. doi:10.3832/ifor0901006

Heriansyah I, Miyakuni K, Kato T, Kiyono Y, Kanazawa Y (2007) Growth characteristics and biomass accumulations of Acacia mangium under different management practices in Indonesia. $\mathrm{J}$ Trop For Sci 19:226-235

Houghton RA (2003) Revised estimates of the annual net flux of carbon to the atmosphere from changes in land use and land management 1850-2000. Tellus B 55:378-390

IPCC (2006) IPCC guidelines for national greenhouse gas inventories. Volume 4: agriculture, forestry and other land use. http://www.ipccnggip.iges.or.jp/public/2006gl/vol4.html Accessed 8 Oct 2013

IPCC (2013) Climate change 2013: the physical science basis. Contribution of working group I to the fifth assessment report of the Intergovernmental Panel on Climate Change. Cambridge University Press, Cambridge

Istomo (2002) Kandungan fosfor dan kalsium serta penyebarannya pada tanah dan tumbuhan hutan rawa gambut (studi kasus di wilayah bagian kesatuan pemangkuan hutan bagan, kabupaten rokan hilir, riau). Unpublished Postgraduate thesis (Ph.D), Institut Pertanian Bogor, Indonesia

Jaya A, Siregar UL, Daryono H, Suhartana S (2007) Biomasa hutan rawa gambut tropika pada berbagai kondisi penutupan lahan. Jurnal Penelitian Hutan dan Konservasi Alam 4:341-352

Jenkins JC, Chojnacky DC, Heath LS, Birdsey RA (2003) Comprehensive database of diameter-based biomass regressions for North American tree species. GTR-NE-31, Northeastern Research Station, USDA Forest Service, Newtown Square, PA, USA, $45 \mathrm{p}$.

Joseph S, Herold M, Sunderlin WD, Verchot LV (2013) REDD+ readiness: early insights on monitoring, reporting and verification systems of project developers. Environ Res Lett 8:034038

Kartawinata K, Jessup TC, Vayda AP (1989) Exploitation in Southeast Asia. In: Lieth H, Werger MJA (eds) Tropical rain forest ecosystems: biogeographical and ecological studies. Elsevier, Amsterdam, pp 591-610 
Kenzo T, Ichie T, Hattori D, Itioka T, Handa C, Ohkubo T, Kendawang JJ, Nakamura M, Sakaguchi M, Takahashi N (2009a) Development of allometric relationships for accurate estimation of above and belowground biomass in tropical secondary forests in Sarawak, Malaysia. J Trop Ecol 25:371-386

Kenzo T, Furutani R, Hattori D, Kendawang JJ, Tanaka S, Sakurai K, Ninomiya I (2009b) Allometric equations for accurate estimation of above-ground biomass in logged-over tropical rainforests in Sarawak, Malaysia. J For Res 14:365-372. doi:10.1007/s10310009-0149-1

Ketterings QM, Coe R, van Noordwijk M, Ambagau Y, Palm CA (2001) Reducing uncertainty in the use of allometric biomass equations for predicting aboveground tree biomass in mixed secondary forests. For Ecol Manag 146:199-209

Krisnawati H, Adinugroho WC, Imanuddin R (2012) Monograf Modelmodel alometrik untuk pendugaan biomassa pohon pada berbagai tipe ekosistem di Indonesia. Pusat Penelitian dan Pengembangan Konservasi dan Rehabilitasi, Badan Penelitian dan pengembangan Kehutanan. Kementria Kehutanan

Langi YAR (2007) Model penduga biomassa dan karbon pada tegakan hutan rakyat cempaka (Elmerrillia ovalis) dan Wasian (Elmerrillia celebica) di kabupaten minahasa sulawesi utara. Unpublished postgraduate thesis, Institut Pertanian Bogor

Leuschner C, Moser G, Bertsch C, Röderstein M, Hertel D (2007) Large altitudinal increase in tree root/shoot ratio in tropical mountain forests of Ecuador. Basic Appl Ecol 8:219-230

Levine JS (1999) The 1997 fires in Kalimantan and Sumatra, Indonesia: gaseous and particulate emissions. Geophys Res Lett 26:815-818

MacKinnon K, Hatta G, Halim H, Mangalik A (1996) The ecology of Kalimantan: Indonesian Borneo, the ecology of Indonesia series, vol III. Periplus Editions, Hong Kong. ISBN 0-945971-73-7

Manuri S, Putra CAS, Saputra AD (2011) Tehnik pendugaan cadangan karbon hutan. Merang REDD Pilot Project, German International Cooperation - GIZ, Palembang

Manuri S, Noor'an F, Giono G (2012) Destructive sampling dataset of aboveground biomass at PT Intracawood Manufacturing, East Kalimantan. GIZ Forclime and Dipterocarp Research Agency

Manuri S, Kumara I, Kusharyono D, Somala E (2013) Pengembangan persamaan alometrik lokal di kabupaten kapuas hulu. Dinas perkebunan dan kehutanan kabupaten kapuas hulu - forclime GIZ report

Manuri S, Brack C, Nugroho NP, Hergoualc'h K, Novita N, Dotzauer H, Verchot L, Putra CAS, Widyasari E (2014) Tree biomass equations for tropical peat swamp forest ecosystems in Indonesia. For Ecol Manag 334:241-253

Marimpan LS (2010) Inventore hutan alam jenis ampupu (Eucalyptus urophylla) dalam menghasilkan volume kayu batang, biomassa, dan karbon hutan. Unpublished postgraduate thesis, Universitas Gadjah Mada

Marshall AJ, Beehler BM (2007) The ecology of Papua: part 2. Periplus editions, Hong Kong, 768 p

Masripatin N, Ginoga K, Pari G, Dharmawan WS, Siregar CA, Wibowo A, Puspasari D, Utomo AS, Sakuntaladewi A, Lugina M, Indartik WW, Darmawan S, Heryansah I, Heriyanto NM, Siringoringo HH, Damayanti R, Anggraeni D, Krisnawati H, Maryani R, Apriyanto D, Subekti B (2010) Cadangan Karbon Pada Berbagai Tipe Hutan dan Jenis Tanaman di Indonesia. Pusat Penelitian dan Pengembangan Perubahan Iklim dan Kebijakan, Bogor

Massiri SDG (2010) Biomassa dan karbon pada kondisi mature building dan gap di hutan hujan tropis. Unpublished postgraduate thesis, Universitas Gadjah Mada

Maulana SI, Asmoro JPA (2011a) Persamaan Allometrik Genera Intsia sp. Untuk Pendugaan Biomassa Atas Tanah Pada Hutan Tropis Papua Barat. Jurnal Penelitian Sosial dan Ekonomi Kehutanan 7: 275-284
Maulana SI, Asmoro JPA (2011b) Persamaan-persamaan allometrik untuk Pendugaan total biomassa atas tanah pada Genera pometia di kawasan hutan tropis papua. Jurnal Penelitian Sosial dan Ekonomi Kehutanan 8:288-298

Miettinen J, Shi C, Liew SC (2011) Deforestation rates in insular Southeast Asia between 2000 and 2010. Glob Chang Biol 17: $2261-2270$

Miyamoto K, Rahajoe JS, Kohyama T, Mirmanto E (2007) Forest structure and primary productivity in a Bornean heath forest. Biotropica 39:35-42. doi:10.1111/j.1744-7429.2006.00231.x

Monk KA, De Fretes Y, Reksodiharjo-Lilley G (1997) The ecology of nusa tenggara and maluku. The ecology of Indonesian series v., periplus editions. Periplus Editions Ltd, Hong Kong 9. ISBN 962593-076-0

Niapele S (2011) Estimasi biomassa dan tegakan dipterocarpaceae di pt sari bumi kusuma (SBK) kalimantan tengah. Unpublished postgraduate thesis, Universitas Gadjah Mada, Indonesia

Novita N (2010) Potensi karbon terikat di atas permukaan tanah pada hutan gambut bekas tebangan di merang sumatera selatan. Unpublished postgraduate thesis, Institut Pertanian Bogor, Indonesia

Overman JPM, Witte HJL, Saldarriaga JG (1994) Evaluation of regression models for above-ground biomass determination in Amazon rainforest. J Trop Ecol 10:207-218

Page SE, Siegert F, Rieley JO, Boehm H-DV, Jaya A, Limin S (2002) The amount of carbon released from peat and forest fires in Indonesia during 1997. Nature 420:61-65

Persch S (2010) Carbon stock in above ground and coarse root biomass in different land use treatments on tropical peat. Unpublished postgraduate thesis, University of Göttingen

Romijn E, Ainembabazi JH, Wijaya A, Herold M, Angelsen A, Verchot L, Murdiyarso D (2013) Exploring different forest definitions and their impact on developing REDD+ reference emission levels: a case study for Indonesia. Environ Sci Pol 33:246-259

Rutishauser E, Noor'an F, Laumonier Y, Halperin J, Rufi'ie, Hergoualc'h K, Verchot LV (2013) Generic allometric models including height best estimate forest biomass and carbon stocks in Indonesia. For Ecol Manag 307:219-222

Saatchi SS, Harris NL, Brown S, Lefsky M, Mitchard ETA, Salas W, Zutta BR, Buermann W, Lewis SL, Hagen S, Petrovac S, Whiteh L, Silmani M, Morelj A (2011) Benchmark map of forest carbon stocks in tropical regions across three continents. Proc Natl Acad Sci U S A 108:9899-9904

Samalca IK (2007) Estimates of forest biomass and its error: a case study in Kalimantan, Indonesia. Unpublished postgraduate thesis, International Institute for Geo-Information Science and Earth Observation, Enschede

Siregar CA, Dharmawan IWS (2011) Stok Karbon Tegakan Hutan Alam Dipterokarpa Di PT. Sarpatim, Kalimantan Tengah. Jurnal Penelitian Hutan dan Konservasi Alam 8:337-348

Stas MS (2011) Above ground biomass and carbon stocks in a secondary forest in comparison with adjacent primary forest on limestone in Seram, the Moluccas, Indonesia. Unpublished postgraduate thesis, Utrecht University, The Netherlands

Sutaryo D (2009) Penghitungan biomassa: sebuah pengantar untuk studi karbon dan perdagangan karbon. Wetlands International Indonesia Programme

Suwarna U, Elias, Darusman D, Istomo (2012) Estimasi simpanan Karbon Total dalam Tanah dan Vegetasi Hutan Gambut Tropika di Indonesia. Jurnal Manajemen Hutan Tropika 38:118-128

van Breugel M, Ransijn J, Craven D, Bongers F, Hall JS (2011) Estimating carbon stock in secondary forests: decisions and uncertainties associated with allometric biomass models. For Ecol Manag 262:1648-1657

van Steenis CGGJ (1957) Outline of vegetation types in Indonesia and some adjacent regions. Proc Pac Sci Congr 8:61-97 
Verchot LV, Anitha K, Romijn E, Herold M, Hergoualc'h K (2012) Emissions factors: converting land use change to $\mathrm{CO}_{2}$ estimates. In: Angelsen A, Brockhaus M, Sunderlin WD, Verchot LV (eds) Analysing REDD+: challenges and choices. CIFOR, Bogor, pp 261-278

Vieilledent G, Vaudry R, Andriamanohisoa SFD, Rakotonarivo OS, Randrianasolo HZ, Razafindrabe HN, Rakotoarivony CB, Ebeling J, Rasamoelina M (2012) A universal approach to estimate biomass and carbon stock in tropical forests using generic allometric models. Ecol Appl 22:572-583

Walker WA, Baccini M, Nepstad N, Horning N, Knight D, Braun E, Bausch A (2011) Field guide for forest biomass and carbon estimation. Version 1.0. Woods Hole Research Center, Falmouth

Wallace AR (1869) The Malay archipelago. Harper and Brothers, New York

West GB, Brown JH, Enquist BJ (1997) A general model for the origin of allometric scaling laws in biology. Science 276:122-126

West GB, Brown JH, Enquist BJ (1999) A general model for the structure and allometry of plant vascular systems. Nature 400:664-667

Whitmore TC (1982) Wallace's line: a result of plate tectonics. Ann Mo Bot Gard 69:668-675

Whitmore TC (1984) A vegetation map of Malesia at scale 1:5 million. J Biogeogr 11:461-471

Widyasari NAEH (2010) Pendugaan biomassa dan potensi karbon terikat di atas permukaan tanah pada hutan gambut merang bekas terbakar di sumatera selatan. Unpublished postgraduate thesis, Institut Pertanian Bogor, Indonesia

Yamakura T, Hagihara A, Sukardjo S, Ogawa H (1986a) Above ground biomass of tropical rainforest stands in Indonesian Borneo. Vegetatio 68:71-82

Yamakura T, Hagihara A, Sukardjo S, Ogawa H (1986b) Tree size in a mature dipterocarp forest stand in sebulu, east Kalimantan, Indonesia. Southeast Asian Stud 23:452-478

Yeza A (2012) Estimasi biomassa dan karbon akar di hutan hujan tropis pada areal bekas tebangan (PT. SBK Kalimantan Tengah). Unpublished undergraduate thesis, Universitas Gadjah Mada

Yunianto AS (2012) Estimasi biomassa dan karbon batang, cabang, dan daun beberapa jenis pohon hutan tropika basah pada areal bekas tebangan PT. Sari bumi kusuma, kalimantan tengah. Unpublished undergraduate thesis, Universitas Gadjah Mada

Zanne AE, Lopez-Gonzalez G, Coomes DA, Ilic J, Jansen S, Lewis SL, Miller RB, Swenson NG, Wiemann MC, Chave J (2009) Data from: towards a worldwide wood economics spectrum. Dyrad Digital Repository. http://datadryad.org/handle/10255/dryad.235 Accessed 20 Dec 2013

Zianis D, Muukkonen P, Mäkipää R, Mencuccini M (2005) Biomass and stem volume equations for tree species in Europe. Silva Fenn Monogr 4:63 